\title{
Perancangan Komunikasi Visual Sunnah dalam Adab Berpakaian untuk Anak
}

\author{
Aryadwipa Angesti Faradhiga \\ Mahasiswa Desain Komunikasi Visual \\ Program Pascasarjana Institut Seni Indonesia Yogyakarta \\ faradhigaarya@gmail.com
}

\begin{abstract}
Islam is a religion known as a doctrine of belief that contains various kinds of command and prohibitions in its inside, one of that is the command that directs about courtesy in a dressing. The general function of clothing is to cover body parts that forbidden to seen or in other words called aurat. But in practice, not yet all Moslem apply and obey the law/shari'ah well and correctly, especially in Indonesia.

This design persuades the target audience, namely children and parents to jointly agree on guidelines for applying the sunnah rules that are conveyed. The design method is implementing Tim Brown's design thinking approach that useful for combining the results of analysis and creative ideas. The method of design thinking approach consists of five stages, empathize, define, ideate, prototype, and test. Data analysis uses a $5 W+1 H$ approach to determine design goals, target audience, and problem-solving methods.
\end{abstract}

The book designing is entitled 'Mengenal Sunnah dalam Adab Berpakaian' applying descriptive story approaches to convey its message. The visual message is conveyed through character design consisting of the character of boys and girls. Illustration and layout done by rough sketch, and then visualised into digital. Supporting media used such as pins and posters.

Keywords: Children's book, illustration book, sunnah of dressing

Relevance to Visual Comunication Design Practice: As a reference and alternative visual communication design solutions for designers and researchers, for academic or practical needs.

\section{LATAR BELAKANG MASALAH}

Agama Islam adalah agama yang dikenal sebagai suatu ajaran kepercayaan yang di dalamnya mengandung berbagai macam perintah dan larangan, dengan tujuan membimbing pemeluknya menuju ke jalan yang benar, sebagai contoh Islam mengajarkan bagaimana cara untuk mendekatkan diri kepada sang pencipta melalui ibadah sholat dan berdoa, mengajarkan bagaimana sikap dalam berinteraksi antar sesama manusia seperti bersilaturahim, tolong menolong, sedekah, saling mengingatkan dan mengajak kepada kebaikan. Secara umum ajaran-ajaran kebaikan yang ada dalam agama Islam sama dengan ajaran yang dimiliki oleh kepercayaan lainnya, tetapi ada beberapa perintah dan larangan yang menjadi pembeda dalam ajaran agama Islam, salah satunya adalah ajaran yang mengatur tentang adab dalam berpakaian.

Fungsi umum dari pakaian adalah untuk menutupi bagian tubuh yang tidak boleh terlihat atau dalam kata lain aurat, AlNawawiy (2007: 18) dalam bukunya yang berjudul Hukum Islam Seputar Busana \& Penampilan Wanita mendefinisikan bahwa aurat adalah al-nuqshaan wa al-syai' almustaqabbih (kekurangan dan sesuatu yang mendatangkan celaan). Diantara bentuk pecahan katanya adalah awara yang 
bermakna qabiih (tercela), yakni aurat manusia dan semua yang bisa menyebabkan rasa malu, disebut aurat karena tercela bila terlihat (ditampakkan).

Jika merujuk pada sumber perintah dan larangannya seperti yang tertulis juga pada buku tersebut, pria dan wanita muslim memiliki batasan aurat yang berbeda, aurat pria muslim adalah antara pusar dan lutut, sedangkan aurat wanita muslim adalah seluruh bagian tubuhnya kecuali wajah dan kedua telapak tangan. Namun pada praktiknya belum semua pemeluk agama Islam menerapkan dan mematuhi hukum/syari'at tersebut dengan baik dan benar, khususnya di Indonesia, masih banyak umat muslim yang dalam aktifitas kesehariannya mengenakan pakaian yang bentuk dan ukurannya menyimpang dari syari'at Islam yang diperintahkan, hal tersebut dengan sangat mudah dapat dijumpai di lingkungan sekitar seperti celana pria yang panjangnya melebihi mata kaki, panjang rok wanita yang tidak sepenuhnya menutupi bagian kaki ketika sedang mengendarai kendaraan bermotor, lipatan atau jenis jilbab yang tidak sempurna sehingga masih menampakkan helai rambut, dan kekeliruan dalam menjalankan perintah menutup aurat lainnya.

Jika dipandang dari bentuk penerapan budaya, masyarakat muslim pada hakikatnya sudah cukup mematuhi nilai dan norma yang berlaku di tengah-tengah masyarakat bahwa mengenakan pakaian adalah sebagai tujuan untuk menutup bagian tubuh dan menunjukkan sikap kesopanan di depan kelompok masyarakat lainnya, akan begitu norma yang dibawa oleh kebudayaan belum sepenuhnya mengandung norma yang dibawa oleh ajaran agama Islam, masyarakat patuh hanya pada perintah yang dibawa oleh budaya tetapi tidak menelaah dan seakan-akan mengabaikan perintah agama.

Mirisnya, sekolah-sekolah dan yayasan pendidikan yang berorientasi pada materi pelajaran serta ilmu agama justru turut luput dalam menyikapi perintah agama yang berkaitan dengan adab berpakaian tersebut. Muncul permasalahan di lingkungan muridmurid sekolah Islam, seragam sekolah yang diberikan kepada murid-murid beberapa PAUD, sekolah dasar atau madrasah ibtidaiyah (MI), hingga ke jenjang sekolah menengah (MTS dan MA) tidak memperhatikan kaidah batasan yang diwajibkan bagi laki-laki dan perempuan muslim. Pendidikan dan sosialisasi adab berpakaian sesuai syariat Islam seharusnya sudah diajarkan sejak dini, agar anak-anak muslim bisa mengetahui, memahami, dan terbiasa dengan jenis pakaian yang wajib mereka terapkan dalam aktifitas sehari-hari atau ketika berinteraksi dengan orang lain, sehingga ketika anak-anak sudah beranjak dewasa mereka tidak lagi mempermasalahkan gaya berpakaian mereka yang dinilai seperti laki-laki atau perempuan Arab ataupun harus melewati masa-masa tidak nyaman karena belum terbiasa dengan pakaian yang berukuran besar dan serba tertutup khususnya bagi perempuan muslim.

Sebagai upaya untuk menyikapi permasalahan tersebut, perlu kiranya dirancang sebuah media yang dapat dijadikan media pengenalan dan pembelajaran bagi anak dibawah umur tentang adab berpakaian sesuai syari'at Islam yang meliputi pembagian kewajiban menutup aurat, pengenalan jenis dan karakter pakaian, tata cara dan 
penggunaannya yang disertai dengan pengertian dan penjelasan berdasarkan perintah dan hukum Islam yang merujuk pada Al-Qur'an, hadits, dan sumber-sumber keagamaan lainnya yang disampaikan secara informatif disertai dengan grafis yang menarik namun tetap mengutamakan pesan penting yang ingin disampaikan. Perancangan ini mengajak target audiens yakni anak-anak dan orang tua untuk bersama-sama menyepakati pedoman menerapkan kaidah sunnah yang disampaikan. Kesepakatan tersebut diharapkan berbuah pada implementasi yang konsisten, yakni menerapkan kaidah yang sama dengan beragam cara untuk konteks yang berbeda-beda.

Melihat aktifitas keseharian anak-anak yang masih banyak berkutat dengan buku, baik itu buku materi pelajaran ataupun buku cerita bergambar, membuat buku menjadi menarik untuk dimanfaatkan sebagai media pengantar pesan. Buku memiliki keunggulan dalam menyediakan konten secara berulang tanpa terpaut pada ruang dan waktu, sehingga buku bisa diakses kapan saja dan dimana saja. Seorang peneliti dari Stavanger University di Norwegia, Anne Mangen, menyatakan bahwa mereka yang membaca buku fisik memiliki kemampuan dalam mengingat kembali alur cerita yang dikisahkan. Pernyataan ini diperkuat oleh studi yang dilakukan oleh sebuah tim penelitian di University of Iowa, Amy Poremba selaku profesor di Departemen Psikologi menyatakan bahwa manusia membutuhkan tampilan visual dan sentuhan dalam mengingat informasi.

Maka dari itu dengan dirancangnya komunikasi visual tentang sunnah adab berpakaian sebagai media komunikasi yang informatif dan edukatif bagi anak usia dini, diharapkan dapat lebih mengubah cara berfikir masyarakat muslim tentunya para orang tua dalam menyikapi hal ihwal yang menjadi perintah dan larangan di dalam ajaran dan syari'at Islam untuk kemudian apa yang sudah menjadi tanggung jawab dan kewajiban tersebut dapat diajarkan kepada anak-anak mereka. Sehingga masyarakat muslim yang sudah mengenal dan terbiasa dengan gaya berbusana yang sesuai dengan apa yang diperintahkan oleh agama dapat mengambil hikmah dan manfaat yang ternilai dari menutup aurat seperti kehormatan diri yang terjaga, terhindar dari tindak pelecehan seksual, dapat membedakan secara identitas dengan masyarakat bukan muslim, dan yang terpenting adalah ciri seorang umat yang patuh terhadap perintah Tuhannya.

Diharapkan perancangan ini dapat menginspirasi para guru dan tenaga pengajar ilmu agama yang banyak berinteraksi dengan murid-muridnya untuk lebih serius dalam menyikapi permasalahan perintah dan larangan agama yang ada disekitar masyarakat bukan hanya dari adab berpakaian saja, serta dapat mendorong keinginan untuk saling mengingatkan satu sama lain kepada kebaikan.

\section{RUMUSAN MASALAH}

Bagaimana merancang komunikasi visual penerapan sunnah dalam adab berpakaian untuk anak?

\section{TUJUAN DAN MANFAAT}

\section{Tujuan}

Perancangan komunikasi visual bertujuan untuk memberi pemahaman yang sesuai kepada anak-anak tentang sunnah dalam 
adab berpakaian, disebut adab karena tentu saja bukan sekedar tuntunan menutup aurat, tetapi juga termasuk cara dan kebiasaan baik yang menyertai penerapannya, termasuk anjuran dan larangannya.

\section{Manfaat Praktis}

1. Sebagai sumber referensi dan media bagi orang tua, guru, ustadz atau ustadzah untuk mengajarkan implementasi sunnah dalam adab berpakaian kepada anak atau murid.

2. Mendukung lembaga dan yayasan kegamaan untuk berdakwah mengajak kepada kebaikan dan meluruskan pemahaman melalui desain komunikasi visual.

3. Meluruskan paradigma masyarakat tentang sunnah dalam adab berpakaian yang masih banyak diabaikan.

4. Mendukung perkembangan industri kreatif berupa konsep dan rancangan untuk media edukasi dan religi.

\section{Manfaat Teroritis}

1. Sebagai sumber referensi dan kajian ilmu perancangan desain komunikasi visual, yakni perancangan yang bertujuan untuk memecahkan permasalahan yang berkaitan dengan fenomena agama.

2. Sebagai sumber referensi dan alternatif solusi permasalahan desain komunikasi visual bagi perancang maupun peneliti karya desain.

\section{ANALISIS DATA}

Analisis data adalah cara atau metode yang digunakan guna menarik asumsi dan kesimpulan sementara berdasarkan hasil data primer dan sekunder yang telah disusun untuk kemudian digunakan sebagai dasar acuan penentuan konsep kreatif dan perancangan desain agar strategi pemecahan masalah yang ingin dicapai sesuai dengan konteks permasalahan yang ada dan tepat sasaran. Maka pendekatan yang digunakan adalah dengan menggunakan metode $5 \mathrm{~W}+$ 1H. Pendekatan $5 \mathrm{~W}+1 \mathrm{H}$ adalah metode analisis data yang menggunakan kalimat pertanyaan sebagai cara untuk memperoleh jawaban berupa sebab dan akibat atas suatu fenomena.

\section{What, Apa yang ingin disampaikan?}

Tentang sunnah dalam adab berpakaian yang masih sering diabaikan atau tidak diketahui masyarakat muslim. Sunnah dalam adab berpakaian merupakan simbol bagaimana seorang muslim seharusnya berinteraksi melalui adab yang menjadi salah satu pembentuk karakter atau ciri eksistensi masyarakat muslim, yang membedakan dengan pemeluk agama lain.

\section{Where, Dimana perancangan akan diterapkan?}

Perancangan akan di terapkan di kota Yogyakarta, tepatnya di daerah Mantrijeron, karena entitas objek permasalahan banyak ditemukan bersosialisasi dan bermukim di daerah ini. Mantrijeron adalah wilayah dengan kepadatan interaksi sosial masyarakat muslim, sebab dalam satu wilayah Mantrijeron terdapat pesantren bernama AlMunawwir, Masjid Jogokaryan, SD Islam Jageran, dan Madrasah Aliyah Ali Maksum. 
When, Kapan perancangan akan dipublikasikan?

Perancangan akan diterbitkan pada harihari menjelang bulan ramadhan hingga hari raya Idul Fitri. Bulan ramadhan menjadi waktu yang tepat untuk mengkampanyekan ajakan mengenal sunnah dalam adab berpakaian, sebab pada bulan ini seluruh umat muslim dari usia muda hingga tua berlomba-lomba untuk memperbaiki amal ibadah dan penampilan. Maka diharapkan media perancangan menjadi salah satu pedoman dalam menentukan jenis pakaian yang akan digunakan target audiens selama beribadah di bulan ini, sehingga saat Idul Fitri tiba, target audiens sudah mengimplementasikan adab berpakaian yang sesuai sunnah.

\section{Who, Siapa target audiens perancangan?}

Target audiens adalah anak-anak muslim, laki-laki dan juga perempuan dalam rentang usia 6 hingga 11 tahun, yang mana pada umur ini anak-anak masih mengenyam pendidikan di bangku sekolah dasar. Pada rentang usia tersebut anak masih dalam proses pertumbuhan dan perkembangan, anak masih terbuka dengan hal-hal baru yang membangun rasa ingin tahu dan minat eksploratifnya, sehingga menanamkan ajaran serta pemahaman masih berpotensi untuk diterima oleh anak.

\section{Why, Mengapa perancangan ini penting?}

Melihat banyaknya masyarakat yang belum menerapkan sunnah dalam adab berpakaian, padahal sunnah juga merupakan amalan yang dianjurkan dalam agama. Maka untuk membiasakan seseorang dalam mengenal sunnah perlu untuk diajarkan dan diberi praktik sejak dini, karena pada masa tersebut tepat untuk anak dalam menyerap pendidikan agama (nilai dan norma) dan itu akan menjadi bekal yang baik dimasa remajanya dalam beraktifitas sealigus beragama.

\section{How, Bagaimana pesan disampaikan?}

Perancangan ini menerapkan pendekatan cerita deskriptif untuk menyampaikan pesannya, dan konten cerita yang disesuaikan dengan kebutuhan permasalahan. Pesan juga disampaikan melalui desain karakter yang terdiri dari karakter anak laki-laki dan perempuan.

Selain itu dikarenakan bentuk asal perintah atau hadits yang menjelaskan tentang adab berpakaian masih berbentuk kalimat dogmatik, masih sulit untuk dimengerti oleh anak-anak maksud dan keutamaan dari hadits tersebut. Maka untuk memudahkan anak dalam memahami kandungan hadits, dibuat cerita yang mendeskripsikan kalimat dogmatik menjadi kalimat deskriptif yang berisikan maksud dan intisari dari hadits, dengan gaya bahasa yang menyesuaikan pemahaman si anak agar isi perintah dan beberapa istilah bahasa arab menjadi mudah dipahami.

\section{LANDASAN TEORI}

\section{Desain Komunikasi Visual}

Pemikiran desain komunikasi visual yang digunakan adalah yang memiliki konsep untuk mengarahkan cara berfikir dan membentuk tujuan dalam merancang konsep dan pesan perancangan. Mengutip pendapat 
A.D. Pirous yang ditulis oleh Sumbo Tinarbuko (2015: 8) dalam bukunya yang berjudul DEKAVE. Menurutnya desain komunikasi visual yang dalam bentuk kehadirannya seringkali perlu ditunjang dengan suara, suara pada hakikatnya adalah suatu bahasa. Tugas utamanya adalah membawakan pesan dari seseorang, lembaga, atau kelompok masyarakat tertentu kepada orang lain. Sebagai bahasa, maka efektifitas penyampaian pesan tersebut menjadi pemikiran utama seorang desainer komunikasi visual. Untuk itu, seorang desainer haruslah:

1. Memahami betul seluk beluk bentuk pesan yang ingin disampaikan.

2. Mengetahui kemampuan menafsir serta kecenderungan kondisi fisik maupun psikis kelompok masyarakat yang menjadi sasaran.

3. Harus dapat memilih jenis bahasa dan gaya bahasa yang serasi dengan pesan yang dibawakannya. Selain itu juga tepat untuk dibicarakan secara efektif, jelas, mudah, dan mengesankan bagi si penerima pesan.

\section{Pendekatan Pendidikan Anak}

Anak memiliki karakteristik yang berbeda dengan orang dewasa dalam berperilaku dan berfikir. Oleh karenanya dalam hal belajar dan memaknai informasi pun, anak juga memiliki metode yang tidak sama pula dengan orang dewasa. Karakteristik cara belajar anak merupakan kondisi yang harus dipahami dan dijadikan pedoman dalam merencanakan jenis pesan dan membawakannya untuk anak. Adapun karakteristik cara belajar anak menurut Masitoh (2009: 6.9-6.12) adalah:

1. Anak belajar melalui bermain.
2. Anak belajar dengan cara membangun pengetahuannya.

3. Anak belajar secara alamiah.

4. Anak belajar paling baik jika apa yang dipelajarinya mempertimbangkan keseluruhan aspek pengembangan, bermakna, menarik, dan fungsional.

Pencapaian tujuan perancangan yakni memberikan pemahaman yang sesuai untuk anak tentang sunnah dalam adab berpakaian, dapat ditempuh dengan strategi pembelajaran melalui pendekatan bercerita, yang memiliki banyak keutamaan dan dampak perkembangan yang baik. Masitoh (2004: 10.6) juga mengidentifikasi manfaat cerita bagi anak, yaitu sebagai berikut:

1. Bagi anak, mendengarkan cerita yang menarik dan dekat dengan lingkungannya merupakan kegiatan yang mengasyikkan.

2. Pendidik dapat memanfaatkan kegiatan bercerita untuk menanamkan nilai-nilai positif pada anak.

3. Kegiatan bercerita juga memberikan sejumlah pengetahuan sosial, nilai-nilai moral dan keagamaan.

4. Pembelajaran dengan bercerita memberikan pengalaman belajar untuk mendengarkan.

5. Dengan mendengarkan cerita, anak dimungkinkan untk mengembangkan kemampuan kognitif, afektif, dan psikomotorik.

6. Membantu anak untuk membangun bermacam-macam peran yang mungkin dipilih anak, dan bermacam layanan jasa yang ingin disumbangkan anak kepada masyarakat. 


\section{Adab Berpakaian dalam Islam}

Adapun telah datang penjelasan didalam dalil-dalil syar'iyah yang menerangkan tentang hukum-hukum berpakain secara rinci dan jelas, disamping itu, syari'at juga telah menjelaskan batasan wajib ukuran berpakaian yang dikatakan telah menutupi aurat. Juga menjelaskan mana saja perkara yang sunnah maupun haram, makruh dan mubah dalam berpakaian, baik dari segi jenis, batasan maupun ukurannya.

Syaikh Amin bin Abdullah asy-Syaqawi (2014: 4-19) menjelaskan dalam bukunya yang berjudul Adab Berpakaian, mengenai adab dan etika dalam berpakaian yang terdiri dari beberapa judul pembahasan, masingmasing judul dijelaskan secara rinci berdasarkan tafsir ayat Al-Quran, hadits nabi, dan pendapat ahli hadits. Pembahasan yang disampaikan oleh Syaikh Amin ini yang akan menjadi dasar pedoman untuk penulisan konten verbal dari perancangan ini.

Adapun judul-judul tersebut yakni:

1. Wajib menutup aurat.

2. Hendaknya tebal dan tidak transparan sehingga menampakkan aurat atau warna kulit dan lekuk tubuh, dan ini berlaku baik pakaian laki-laki maupun wanita.

3. Tidak menyerupai pakaian wanita bagi laki-laki demikian pula tidak menyerupai pakaian laki-laki bagi wanita.

4. Tidak boleh Isbal (melebihi mata kaki) bagi laki-laki. Dan larangan ini mencakup pakaian yang berupa jubah, sarung, celana maupun gamis.

5. Haram memakai pakaian yang ada gambar salib atau bergambar makhluk hidup.

6. Haram memakai pakaian Syuhrah (popularitas).
7. Haram memakai pakaian yang terbuat dari sutera dan memakai emas bagi laki-laki kecuali bila ada $u d z u r$.

8. Diantara perkara sunnah dalam berpakaian ialah memulai dari sisi kanan terlebih dahulu.

9. Disunnahkan ketika memakai pakaian baru untuk membaca do'a.

10. Disunnahkan untuk mengenakan pakaian yang berwarna putih.

11. Dilarang mengenakan pakaian yang dicelup dengan warna kekuningkuningan.

12. Dianjurkan untuk menampakkan nikmat yang diperoleh dalam berpakaian maupun yang lainnya.

13. Memakai minyak wangi.

\section{METODE PERANCANGAN}

Proses perancangan komunikasi visual sunnah dalam adab berpakaian menggunakan mind mapping sebagai pola menemukan permasalahan untuk perancangan. Menerapkan pendekatan design thinking oleh Tim Brown yang berguna untuk menggabungkan pemikiran kreatif dan analisis, kemudian menerapkannya untuk memecahkan permasalahan. Pendekatan design thinking membantu dalam memetakan proses perancangan konsep dan karya menjadi lebih mendalam, terstruktur dan sesuai tujuan.

Metode perancangan menggunakan pendekatan design thinking yang terdiri dari lima tahapan, yakni empathize, define, ideate, prototype, dan test. Adapun penjelasan dari kelima proses pendekatan dapat dijabarkan sebagai berikut. 


\section{Empathize}

Proses empati dilakukan selama dua hari di satu lokasi, yakni Sekolah Dasar Negeri Jageran, Mantrijeron, Yogyakarta. SD Jageran dipilih sebagai sampel lokasi penelitian karena merupakan sekolah yang menerapkan pendidikan agama Islam sebagai kurikulum dan peraturan tata tertib, sehingga memudahkan untuk mengidentifikasi permasalahan karena juga bertepatan dengan target audiens dari perancangan.

Data dan fakta yang dihasilkan dari tahap empati diperoleh melalui penyebaran kuesioner yang menghasilkan 20 responden, sampel terdiri dari orang tua pria dan wanita, dalam rentang umur 25 hingga 40 tahun, dan dengan latar belakang profesi yang berbedabeda. Kemudian perolehan data visual dan catatan berdasarkan hasil pengamatan pribadi penulis di lapangan.

1. Adapun kesimpulan dari proses empati adalah sebagai berikut:

2. Ada sebagian orang tua yang belum mengenal adanya sunnah dalam dalam berpakaian. Anak hanya diharuskan untuk berpakaian rapi dan tertutup pada acaraacara tertentu saja.

3. Lazimnya orang tua dalam mendidik anakanak cenderung menggunakan metode menasehati dan mencontohkan, maka untuk menyampaikan pesan tentang kaidah dalam adab berpakaian, diberikan media yang berguna sebagai alternatif untuk orang tua.

\section{Define}

Data yang sudah terkumpul melalui tahapan empathize, diolah menjadi deskripsi permasalahan yang berupa kalimat tanya.
Rumusan masalah berisi kata kunci yang membantu proses pencarian teori terkait permasalahan, segmentasi target audiens, dan memandu proses berfikir untuk menemukan konsep perancangan yang dapat menjawab pertanyaan rumusan masalah.

Berdasarkan rincian hasil empati di atas, dapat dirumuskan sebuah solusi permasalahan yakni, bagaimana merancang komunikasi visual penerapan sunnah dalam adab berpakaian yang sesuai dengan kebutuhan target audiens?

\section{Ideate}

Mengambil kata kunci yang terdapat pada kalimat rumusan masalah untuk dijadikan dasar pembuatan mind-mapping, mengidentifikasi kata kunci dengan memberikan pertanyaan mengapa dan bagaimana. Pola mind-mapping berguna untuk merincikan segmentasi target, strategi pesan, dan karakter media. Mengumpulkan jawaban penting hasil mind-mapping untuk dijadikan acuan perancangan prototype yang berupa sketsa kasar hingga visualisasi.

\section{Prototype}

Proses mengolah ide dan konsep hasil dari identifikasi pada Ideate menjadi rancangan visual, dapat berupa sketsa kasar atau ilustrasi rancangan desain dengan menetapkan konsep visual, verbal, layout, dan sebagainya. Ketika rancangan desain sudah tersusun, mulai memasuki tahap master design dengan hasil akhir berupa final design.

\section{Test}

Tahapan menentukan media apa yang tepat dengan rancangan prototype. 
Mempertemukan media-media terpilih dengan target audiens untuk mendapatkan respon, adakah kekurangan atau kesulitan dalam penyampaian pesan dan media. melakukan evaluasi berdasarkan hasil pengamatan test dan respon dari audiens.

\section{HASIL DAN PEMBAHASAN}

\section{Konsep Karya}

Penentuan konten karya dalam perancangan ini mengacu pada landasan teori yang dipakai, yang dihubungkan dengan segmentasi target audiens. Hasil sintesis dari teori dan target tersebut menghasilkan konten perancangan yang berisikan isi pesan dan bentuk pesan (pesan visual dan verbal).

\section{Isi Pesan}

Isi pesan yang disisipkan pada perancangan ini adalah, "Mengenal sunnah dalam adab berpakaian, cara dan kebiasaan baik yang menyertai penerapannya, termasuk anjuran dan larangannya."

\section{Bentuk Pesan}

Setelah menentukan isi pesan, konten perancangan yang perlu untuk dirumuskan adalah bentuk pesannya. Dengan kata lain bagaimana pendekatan yang digunakan untuk menyampaikan isi pesan kepada target audiens. Bentuk pesan menggunakan pendekatan bercerita yang menjelaskan suatu perkara hadits dengan penjelasan yang jelas dan mudah dipahami, didasarkan pada bentuk-bentuk kalimat larangan dan anjuran.

\section{Pesan Verbal}

Prinsipnya adalah perancangan menjadi sumber alternatif materi dan pedoman bagi orang tua untuk mengajarkan kepada anak tentang sunnah dalam adab berpakaian. Berdasarkan prinsip tersebut kemudian menyusun judul untuk dijadikan copy pada media perancangan. Judul untuk copy dari perancangan ini adalah 'Mengenal Sunnah dalam Adab Berpakaian'.

Perancangan pesan menggunakan bahasa Indonesia yang diterapkan pada keseluruhan konten verbal. Menggunakan gaya penuturan yang umum dan lugas, artinya gaya bahasa yang biasa digunakan target audiens sehari-hari sehingga penyampaian dan penerimaan pesan menjadi lebih ramah.

\section{Pesan Visual}

\section{Logo}

Untuk membuat media perancangan memiliki identitas visual dan karakter, langkah pertama yang perlu dilakukan adalah dengan membuat rancangan logo/master design. Logo dibuat berdasarkan copy yang sudah ditentukan. Adapun konsep rancangan logo memiliki bentuk dan filosofi sebagai berikut:

1. Logo merupakan visualisasi dari copy 'Mengenal Sunnah dalam Adab Berpakaian'.

2. Jenis logo yang dirancang adalah logotype, yakni logo yang didominasi oleh elemen tipografi.

3. Bentuk keseluruhan logo dibuat dinamis dan dekoratif, untuk memunculkan kesan ramah baca dan menarik perhatian. 
4. Elemen-elemen visual yang melekat pada logo dibuat ekspresif dan berkarakter untuk menyesuaikan dengan karakter target audiens.

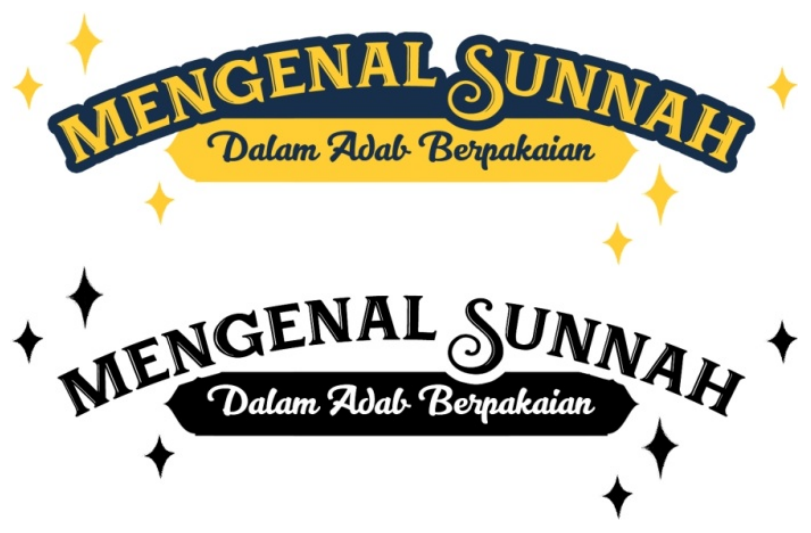

Gambar 1 Rancangan logotype terpilih

Sumber: Dokumentasi penulis

\section{Ilustrasi}

Pemilihan jenis ilustrasi yang akan diterapkan adalah desain karakter laki-laki dan perempuan yang diberi nama Ali (lakilaki) dan Rahma (perempuan). Desain karakter dirancang untuk membuat target audiens lebih mudah menyerap pesan dan menjiwai karakternya. Desain karakter lakilaki dan juga perempuan akan memperagakan gestur yang secara makna mengilustrasikan dari judul pedoman yang disampaikan.

Keseluruhan desain karakter terdiri dari 10 ilustrasi untuk 10 judul pedoman, dengan pembagian lima ilustrasi laki-laki dan lima ilustrasi perempuan. Sebagai penghias bagian latar belakang, akan dilengkapi dengan siluetsiluet lampu gantung atau lampion yang disusun di bagian atas layout, dan untuk bagian bawah layout disisipkan siluet bangunan masjid yang berjejer merata.

Oleh karena itu menyampaikan pesan melalui pendekatan cerita deskriptif yang dilengkapi ilustrasi akan lebih membuat target audiens tertarik untuk mengakses media dan memudahkan dalam proses interpretasi pesan.

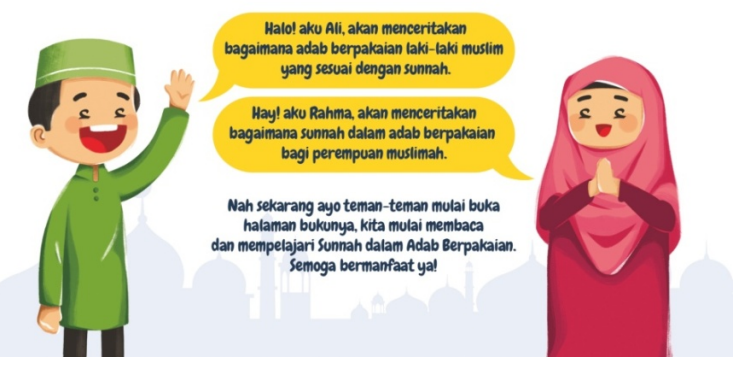

Gambar 2 Desain karakter Ali dan Rahma

Sumber: Dokumentasi penulis

\section{Warna}

Warna yang digunakan terbagi menjadi dua bagian, warna layout media, dan warna yang dipakai untuk identitas desain karakter. Tone warna yang digunakan pada layout media terdiri dari warna biru gelap, kuning, dan hijau. Sedangkan untuk desain karakter menggunakan warna-warna turunan dari warna hijau, merah muda, dan cokelat.

Perpaduan warna yang digunakan pada layout media memiliki makna dan karakteristiknya masing-masing. Warna biru gelap atau dikenal dengan nama indigo blue adalah warna yang terkait dengan kinerja otak kanan, meninjau filosofi warna biru gelap dari perspektif psikologi, warna ini membawa kesan ketulusan dalam merangsang kreativitas dan intuisi, membantu mengembangkan pemikiran dan kecerdasan. Warna kuning membawa makna kehangatan dan keceriaan seolah menimbulkan hasrat untuk bermain. Aura yang terdapat pada warna ini sangat baik digunakan untuk membantu penalaran secara logis dan analitis. Warna yang digunakan untuk layout media adalah perpaduan warna kontras, sebab 
warna kontras cocok digunakan untuk hal-hal yang bertujuan agar cepat dilihat dan menarik perhatian (Sanyoto, 2010: 38).

Adapun warna yang digunakan sebagai identitas karakter yakni hijau dan merah muda. Warna hijau selalu terkait dengan alam, kesehatan, dan ketenangan. Selain itu menurut filosofinya adalah warna yang dapat menenangkan secara fisik yang dapat memproduksi kenaikan respons emosional secara simultan. Hijau juga merupakan warna hasil kombinasi biru dan kuning. Warna merah muda atau pink memberi kesan feminim dan lemah lembut. Warna ini juga memiliki filosofi sebuah transformasi, yakni proses menuju perubahan ke arah yang lebih baik.

\section{C: $0 / M: 20 / Y: 100 / K: 0$ \#FDD100 \\ C: 96 / M: 80 / Y: 44 / K: 41 \#233A54 \\ C: 42 / M: 17 / Y: 75 / K: 0 \#A5BF62 \\ C: 0 / M: 72 / Y: 35 / K: 0 \#EB6D7C}

Gambar 3 Pemilihan warna disertai Decimal code dan Hex code

Sumber: Dokumentasi penulis

\section{Tipografi}

Jenis typeface yang digunakan dalam perancangan Mengenal Sunnah dalam Adab Berpakaian ini adalah berjenis script dan decorative, dikarenakan typeface jenis ini cocok untuk penulisan teks judul dan teks konten dengan karakternya yang mudah terbaca, menarik, dan luwes. Namun juga
Typeface yang dipilih tetap mengutamakan aspek readability dan legibility-nya, mengingat target audiens yang masih usia dini, memerlukan konsentrasi dan kemudahan dalam memproses konten verbal.

Juga pemilihan typeface script dan decorative bertujuan untuk menghadirkan kesan ramah, playfull, dan kekanak-kanakan, hal ini untuk menyesuaikan dengan sifat karakter dan kepribadian anak. Maka berdasarkan pertimbangan di atas jenis typeface yang dipilih adalah sebagai berikut:

Kitten Swash

АВСDEFGนUJKนM NQP2RSTUUGerxyz abcoefghijklmnopgrsturrescyz

\section{CHEWY \\ ABCDEFGHOJKLMNOPQRSTUVWXYZ abcdefghijkImnopqrstuvwxyz 1234567890}

Gambar 4 Typeface Kitten Swash sebagai teks judul, dan Typeface Chewy sebagai teks konten

Sumber: Dokumentasi penulis

\section{Strategi Media}

Strategi media merupakan kegiatan menentukan media-media yang menjadi prioritas dan sebagai pendukung media utama agar dengan mudah menjangkau target audiens yang sudah ditentukan segmentasinya. Memilih sebuah media yang tepat serta dapat menyesuaikan dengan kebutuhan, terutama media-media yang sering bersinggungan dengan target audiens. Maka dalam strategi menentukan media 
pendukung haruslah tepat, efektif, dan juga efisien.

Perancangan ini memilih buku sebagai media utamanya, sedangkan untuk media pendukungnya akan menggunakan beberapa media yang berkaitan dengan fungsional ke media utama dan media yang umum digunakan target audiens. Adapun mediamedia pendukung yang digunakan meliputi pin dan poster.

\section{VISUALISASI}

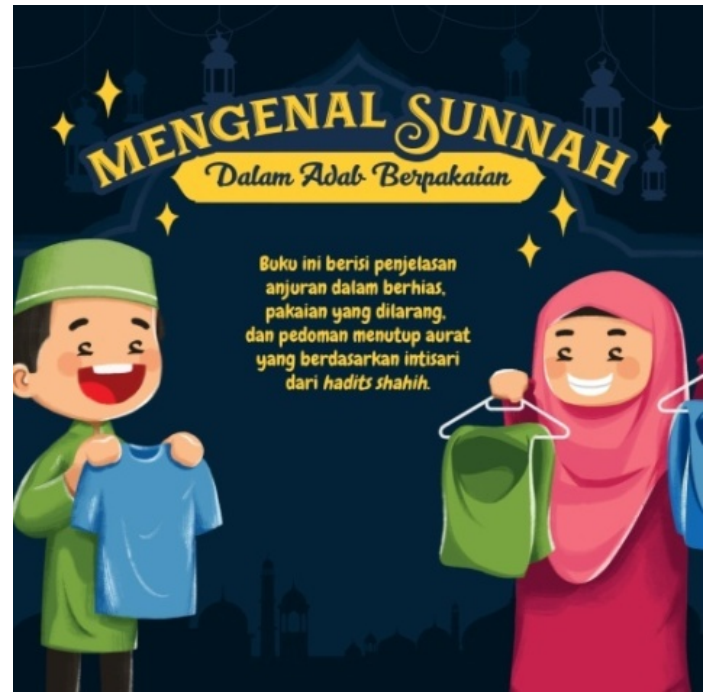

Gambar 5 Desain ilustrasi sampul depan Sumber: Dokumentasi penulis

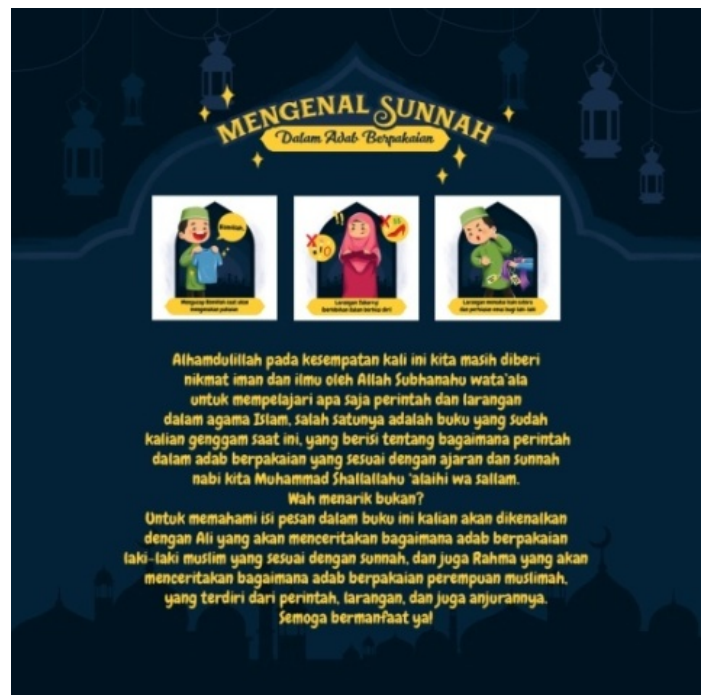

Gambar 6 Desain ilustrasi sampul belakang Sumber: Dokumentasi penulis

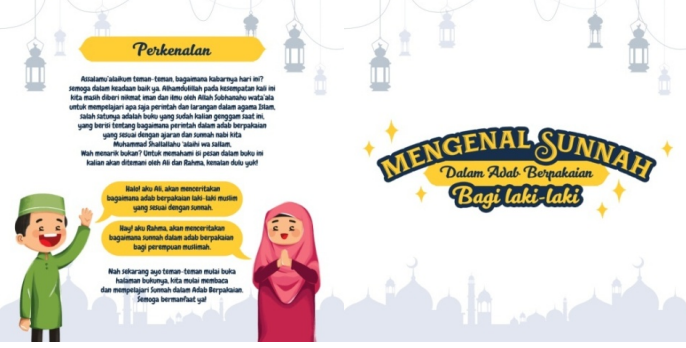

Gambar 7 Desain ilustrasi halaman pembuka Sumber: Dokumentasi penulis
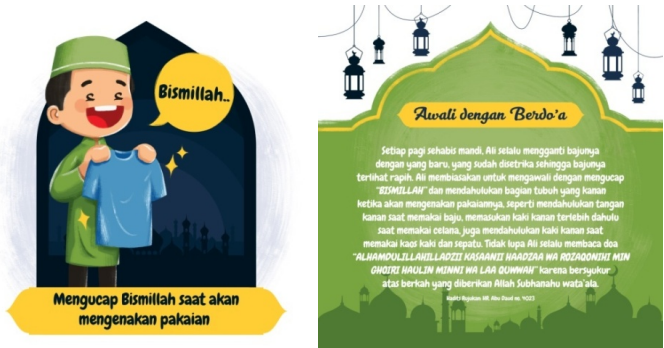

Gambar 8 Desain layout ilustrasi dan konten verbal bab laki-laki

Sumber: Dokumentasi penulis
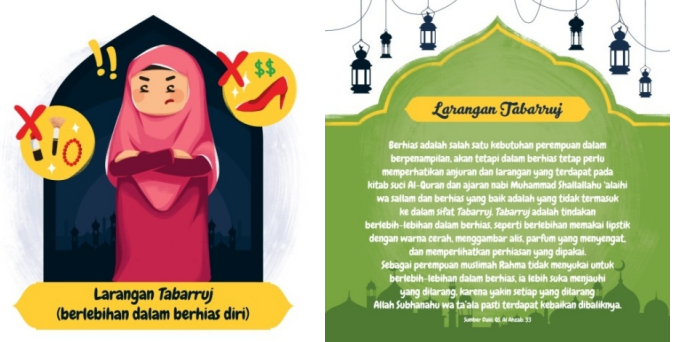

Gambar 9 Desain layout ilustrasi dan konten verbal bab perempuan

Sumber: Dokumentasi penulis
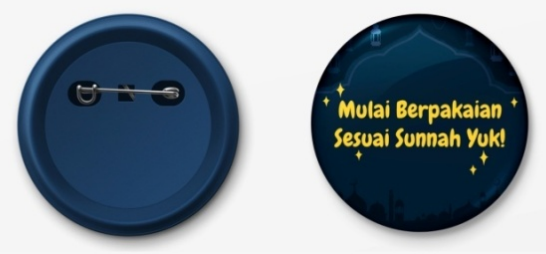

Gambar 10 Media pendukung pin

Sumber: Dokumentasi penulis 


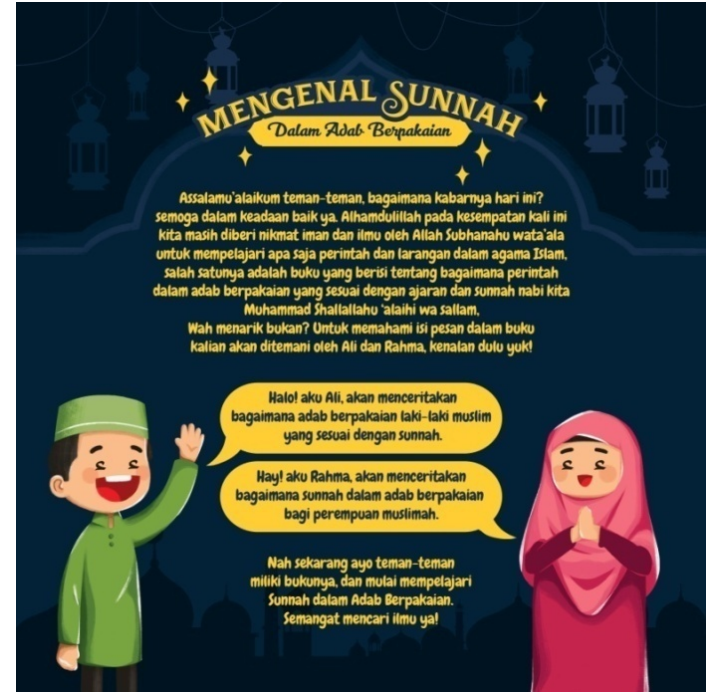

Gambar 11 Media pendukung poster

Sumber: Dokumentasi penulis

\section{KESIMPULAN}

Perancangan komunikasi visual Mengenal Sunnah dalam Adab Berpakaian ini bertujuan untuk memberi pemahaman yang sesuai kepada anak-anak dan orang tua tentang adanya sunnah dalam adab berpakaian. Pendekatan design thinking membantu dalam memetakan proses perancangan konsep dan karya menjadi lebih mendalam, terstruktur dan sesuai tujuan.

Proses pencarian ide dan konsep telah melalui berbagai tahap teoritis dan praktis. Tahap teoritis yakni mencari dan menyandarkan konsep pada teori-teori solutif seperti desain komunikasi visual sebagai teori dasar berfikir dan penyampaian pesan, teori pendidikan anak sebagai metode untuk menemukenali pendekatan yang tepat dalam menghadirkan pesan, dan teori atau dalil syar'i sebagai rujukan pembuatan konten visual dan verbal.

Perancangan ini menjadi problematis karena berupaya untuk membawakan pesan dogmatis kepada anak tentang perintah dan larangan seputar adab dalam berpakaian.
Agar pesan tersebut bisa lebih mudah dipahami makna, bentuk perintah, dan larangannya, maka perlu cara penyampaian yang berbeda dengan tetap berlandaskan pada dogma yang sama, dan dipilihlah cerita deskriptif sebagai pendekatannya.

\section{DAFTAR PUSTAKA}

\section{Buku}

[1] Al-Jaza'iri, Syaikh Abu Bakar Jabir. (2017), Minhajul Muslim, Jakarta: Darul Haq

[2] Al-Nawawiy, Syamsuddin Ramadhan. (2007). Hukum Islam Seputar Busana \& Penampilan Wanita, Yogyakarta: Ar Roudhah Pustaka

[3] Brown, Tim. (2009). Change By Design, New York: HarperCollins

[4] Hakim, Budiman. (2018). Story Telling! Beriklan Lewat Cerita, Yogyakarta: Galang Pustaka

[5] Maharsi, Indiria. (2016). Ilustrasi, Yogyakarta: Badan Penerbit ISI Yogyakarta

[6] Masitoh, dkk. (2009). Strategi Pembelajaran Taman Kanak-Kanak, Tangerang Selatan: Penerbit Universitas Terbuka

[7] Sanyoto, Sadjiman Ebdi. (2010). Nirmana Elemen-Elemen Seni dan Desain, Yogyakarta: Jalasutra

[8] Sihombing, Danton. (2015). Tipografi dalam Desain Grafis, Jakarta: Gramedia Pustaka Utama

[9] Tinarbuko, Sumbo. (2015). DEKAVE Desain Komunikasi Visual - Penanda Zaman Masyarakat Global, Yogyakarta: CAPS Center for Academic Publishing Service

[10] Tinarbuko, Sumbo. (2017). Membaca Tanda dan Makna Desain Komunikasi Visual, Yogyakarta: Badan Penerbit ISI Yogyakarta 
Jurnal

[1] Bigelow, James dan Ami Poremba. (2014). “Achilles' Ear? Inferior Human Short-Term and Recognition Memory in the Auditory Modality". PLoS One 9: e89914. 26 Februari 2014

\section{Karya Ilmiah}

[1] Fauzan, Nur Aji. (2017), "Perancangan Buku Ilustrasi Kumpulan Hadits Pilihan Bagi Anak Dalam Kegiatan Sehari-Hari”. Yogyakarta: Fakultas Seni Rupa, Institut Seni Indonesia Yogyakarta

\section{Situs Web}

[1] Aktual.com. (22 Maret 2016). Adab Fashion Bagi Umat Islam. Diakses 2 Maret 2018 dari http://www.aktual.com/adab-fashionbagi-umat-islam-1/

[2] Aktual.com. (22 Maret 2016). Kesalahan Muslim Muslimah dalam Berpakaian Tidak Sesuai Ajaran Islam. Diakses 2 Maret 2018 dari http://www.aktual.com/kesalahanmuslim-muslimah-dalam-berpakaiantidak-sesuai-ajaran-islam-2/

[3] Borreli, Lizzete. (15 Mei 2015). Hello My Name Is: Why Humans Are Better At facial Recognition Than Remembering Names. Diakses 31 Mei 2018 dari http://www.medicaldaily.com/pulse/hell o-my-name-why-humans-are-betterfacial-recognition-remembering-names333598

[4] InkBot Design. (28 Maret 2018). Logotype vs Logomark Design - What's the Difference. Diakses 5 Juni 2018 dari https://inkbotdesign.com/logotype-vslogomark/

[5] Islamhouse.com. (2014). Adab Berpakaian. Syaikh Amin bin Abdullah asy-Syaqawi. Diakses 1 Juni 2018 dari https://islamhouse.com/id/articles/48283

6/ 